\title{
Rhabdochona spp. (Nematoda: Rhabdochonidae) from fishes in the Central African Republic, including three new species
}

\author{
František Moravec and Miloslav Jirků
}

Institute of Parasitology, Biology Centre of the Academy of Sciences of the Czech Republic, České Budějovice, Czech Republic

\begin{abstract}
Based on light and scanning electron microscopical studies, three new, one already known and one not identified species of the nematode genus Rhabdochona Railliet, 1916 are reported from the intestine of freshwater fishes in Dzanga-Sangha Protected Areas (Congo River basin), the Central African Republic: Rhabdochona (Rhabdochona) centroafricana sp. n. from Barbus miolepis Boulenger, R. (R.) marcusenii sp. n. from Marcusenius greshoffii (Schilthuis), R. (Globochona) paski Baylis, 1928 from Phenacogrammus aurantiacus (Pellegrin) (new host record), R. (G.) tricuspidata sp. n. from Raiamas christyi (Boulenger) and Rhabdochona (G.) sp. (only females) from Epiplatys multifasciatus (Boulenger). Rhabdochona centroafricana is mainly characterised by the length of the left spicule $(333 \mu \mathrm{m})$ and the presence of the operculum bearing a conspicuous gelatinous formation on one of egg poles, $R$. marcusenii by the length of the left spicule (453-486 $\mu \mathrm{m})$ and the presence of a single broad filament on one egg pole only and $R$. tricuspidata by the body with marked cuticular ornamentations and deirids branching into three prongs. A key to valid species of Rhabdochona parasitic in fishes of Africa is provided.
\end{abstract}

Keywords: parasitic nematode, Globochona, freshwater fish, Barbus, Epiplatys, Marcusenius, Phenacogrammus, Raiamas, Congo River basin

The nematode genus Rhabdochona Railliet, 1916 (Rhabdochonidae) comprises a large number of species parasitising freshwater fishes in all zoogeographical regions (Moravec 2010). Khalil and Polling (1997) listed nine species of this genus recorded from freshwater fishes in Africa. Of them, however, R. macrolaima Gendre, 1922, described from a single young female from an unidentified fish in Gambia, was designated a species inquirenda by Moravec (1972), whereas $R$. aegyptiaca El-Nafar et Saoud, 1974, R. congolensis Campana-Rouget, 1961 and $R$. versterae Boomker et Petter, 1993 have recently been synonymised with $R$. paski Baylis, 1928 by Moravec et al. (2013). Since the nematode fauna of freshwater fishes in Africa is little known, it can be expected that additional species of Rhabdochona will be discovered and described.

During recent helminthological investigations of some freshwater fishes in Dzanga-Sangha Protected Areas (DSPA), the Central African Republic, nematodes referable to Rhabdochona were recovered from the intestine of five fish species: Barbus miolepis Boulenger and Raiamas christyi (Boulenger) (both Cyprinidae), Epiplatys multifasciatus (Boulenger) (Nothobranchiidae), Marcusenius greshoffii (Schilthuis) (Mormyridae) and Phenacogrammus aurantiacus (Pellegrin) (Alestidae).

Their detailed study using both light and scanning electron microscopy showed that nematodes from B. miolepis, $M$. greshoffii and $R$. christyi represent three previously undescribed species, that from $P$. aurantiacus an already known species and female specimens from E. multifasciatus were specifically unidentifiable. Results of this study are presented herein.

\section{MATERIALS AND METHODS}

Fish were collected during night, using a hand net and torch in a forest stream near the Mongambe research camp $\left(2^{\circ} 55^{\prime} 4^{\prime \prime} \mathrm{N}\right.$; $\left.16^{\circ} 23^{\prime} 20^{\prime \prime} \mathrm{E}\right)$ in the Dzhanga sector of Dzhanga-Ndoki National Park, or obtained from local fishermen operating on the Sangha River in the vicinity of Sangha Lodge (259'7"N; 16¹3'58"E), within Dzanga-Sangha Special Dense Forest Reserve. Both localities are in DSPA located in the forest zone of the Central African Republic. The nematodes recovered were washed in physiological saline and then fixed in hot $4 \%$ formalin. For light microscopy examination, the nematodes were cleared with glycerine. Drawings were made with the aid of a Zeiss drawing attachment. Specimens used for scanning electron microscopy (SEM) were postfixed in $1 \%$ osmium tetroxide (in phosphate buffer), dehydrated through a graded acetone series, criticalpoint-dried and sputter-coated with gold; they were examined using a JEOL JSM-7401F scanning electron microscope at an accelerating voltage of $4 \mathrm{kV}$ (GB low mode). All measurements are in micrometres unless otherwise indicated. Fishes were identified using vouchers and/or photographs by Melanie L.J. Stiassny of the Department of Ichthyology, American Museum of Natural History (AMNH), New York, USA and Jouke van der Zee, Royal Museum for Central Africa, Tervuren, Belgium. The names of fishes follow FishBase (Froese and Pauly 2013). 


\section{RESULTS}

Rhabdochona (Rhabdochona) centroafricana sp. n.

Figs. 1, 2

Description: Medium-sized nematodes with slightly transversely striated cuticle (Fig. 2C,E,F). Oral opening roughly tetragonal, surrounded by 4 small triangular submedian sublabia, 4 submedian cephalic papillae and pair of lateral amphids (Figs. 1D, 2A,B). Prostom funnel-shaped, armed with 14 anterior teeth (3 dorsal, 3 ventral and 4 lateral on either side); basal teeth slightly outlined (Figs. 1B-D,F, 2A,B). Vestibule straight, relatively long (Fig. 1B). Deirids medium-sized, bifurcate, situated somewhat anterior to middle of vestibule (Figs.1B,C,E,F, 2D). Length ratio of muscular and glandular oesophagus $1: 7.9-10.2$. Tail of both sexes conical, with sharply pointed tip (Figs. 1G,J,K,L, 2C,E).

Male (1 specimen, allotype): Length of body $6.72 \mathrm{~mm}$, maximum width 109 . Length of vestibule including prostom 150; prostom 27 long, 15 wide. Muscular oesophagus 270 long, maximum width 30; glandular oesophagus $2.12 \mathrm{~mm}$ long, maximum width 81 ; length ratio of both parts of oesophagus $1: 7.9$. Entire oesophagus and vestibule representing $38 \%$ of body length. Nerve ring, deirids and excretory pore 195, 57 and 218, respectively, from anterior extremity. Area rugosa absent.

Preanal papillae: 8 pairs of subventral and 1 pair of lateral papillae present; lateral pair located at level of third pair (counting from cloacal opening) of subventrals (Fig. 1K). Postanal papillae: 5 subventral and 1 lateral pairs; lateral pair at level of first pair of subventrals (Figs. 1K, 2E). Pair of small lateral phasmids situated just posterior to last pair of subventral postanal papillae (Fig. 2E).

Left spicule 333 long, length of shaft 120, representing $36 \%$ of spicule length; distal tip of extended spicule broad, bifurcate, provided with large cuticular membrane (Figs. 1I,K, 2E). Right spicule boat-shaped, 111 long, with narrowed dorsal distal end; dorsal barb on distal tip of spicule indistinct (Fig. 1H). Length ratio of spicules $1: 3.00$. Tail 345 long.

Female (1 complete and 3 incomplete gravid specimens; measurements of holotype in parentheses): Length of body 15.82 (15.82) mm, maximum width 163-286 (286). Length of vestibule including prostom 117-162 (162); prostom 21-36 (36) long, 15-24 (21) wide. Muscular oesophagus 246-402 (360) long, maximum width 27-45 (45); glandular oesophagus 1.71-3.67 (3.67) mm long, maximum width 81-150 (111); length ratio of both parts of oesophagus $1: 10.2(1: 10.2)$. Entire oesophagus and vestibule representing 27 (27)\% of body length.

Nerve ring, deirids and excretory pore 144-210 (210), 60-81 (66) and 189-285 (285), respectively, from anterior extremity. Tail conical, 225 (225) long, with pointed tip (Figs. 1G,L, 2C). Pair of distinct lateral phasmids situ- ated at about two thirds of tail (Fig. 2C). Vulva postequatorial, 5.24-9.93 (9.93) $\mathrm{mm}$ from anterior extremity, at $63(63) \%$ of body length; vulval lips not elevated. Vagina directed posteriorly from vulva. Fully developed eggs oval, smooth, thin-shelled, larvated; size $(\mathrm{n}=20)$ 33-36 $\times 21-27(33-36 \times 24-27)$. One egg pole provided with small operculum bearing small but distinct gelatinous formation of irregular shape (Fig. 1M-P).

Type host: Barbus miolepis Boulenger (Cypriniformes: Cyprinidae), standard body length $6.0-7.0 \mathrm{~cm}$.

Site of infection: Intestine.

Type locality: Small forest stream near Mongambe research camp (255'4"N; 16²3'20"E) (Congo River basin), DSPA, Central African Republic (collected 18 September 2012).

Prevalence and intensity of infection: 3 fish infected $/ 3$ fish examined; $1-5$ nematodes per fish.

Deposition of type specimens: Helminthological Collection of the Institute of Parasitology, BC AS CR (IPCAS; $\mathrm{N}$ - 1026). Voucher of symbiotype of B. miolepis is deposited, together with tissue sample in absolute alcohol, in the Department of Ichthyology, American Museum of Natural History, USA (AMNH 260338; field number CAR_T_080).

Etymology: The specific name centroafricana relates to the region where specimens of the new species were collected, i.e. Central Africa.

Remarks. In having 14 anterior prostomal teeth, bifurcate deirids and a sharply pointed tail tip without any ornamentations, specimens of the present material evidently belong to the nominotypic subgenus Rhabdochona in the conception of Moravec (1975). Their morphology is very similar to that of the African species Rhabdochona (R.) gendrei Campana-Rouget, 1961 and $R$. (R.) esseniae Mashego, 1990, both reported from congeneric hosts (Barbus spp.). The former species was originally described by Gendre (1922) from specimens found in Barbus sp. in Gambia, but he incorrectly identified them as Rhabdochona acuminata (Molin, 1860) (a South-American species). Later, based on Gendre's description, Campana-Rouget (1961) established $R$. gendrei. She recorded it from three Barbus spp. in the Democratic Republic of Congo (Lakes Albert, Edward and Kivu), but provided no morphological data; several specimens of her material were subsequently re-examined and described by Moravec (1972). The latter species, $R$. esseniae, was inadequately described by Mashego (1990) from four Barbus spp. in South Africa (the Limpopo and Olifants drainage systems).

The new species distinctly differs from both $R$. gendrei and $R$. esseniae in the length of the left spicule $(333 \mu \mathrm{m}$ vs $480-530 \mu \mathrm{m}$ or $500-560 \mu \mathrm{m}$; see Gendre 1922, Moravec 1972, Mashego 1990) and the shape of its distal tip (widely cleft $v s$ narrow). It can be also differentiated from $R$. gendrei in a much shorter right spicule $(111 \mu \mathrm{m}$ vs $140-170 \mu \mathrm{m})$ and from $R$. esseniae in markedly larger and less elongate eggs $(33-36 \times 21-24 \mu \mathrm{m}$ vs $19-27 \times$ $12-15 \mu \mathrm{m})$. The conspicuous gelatinous formation on one 
Moravec and Jirků: Rhabdochona spp. in Central African Republic

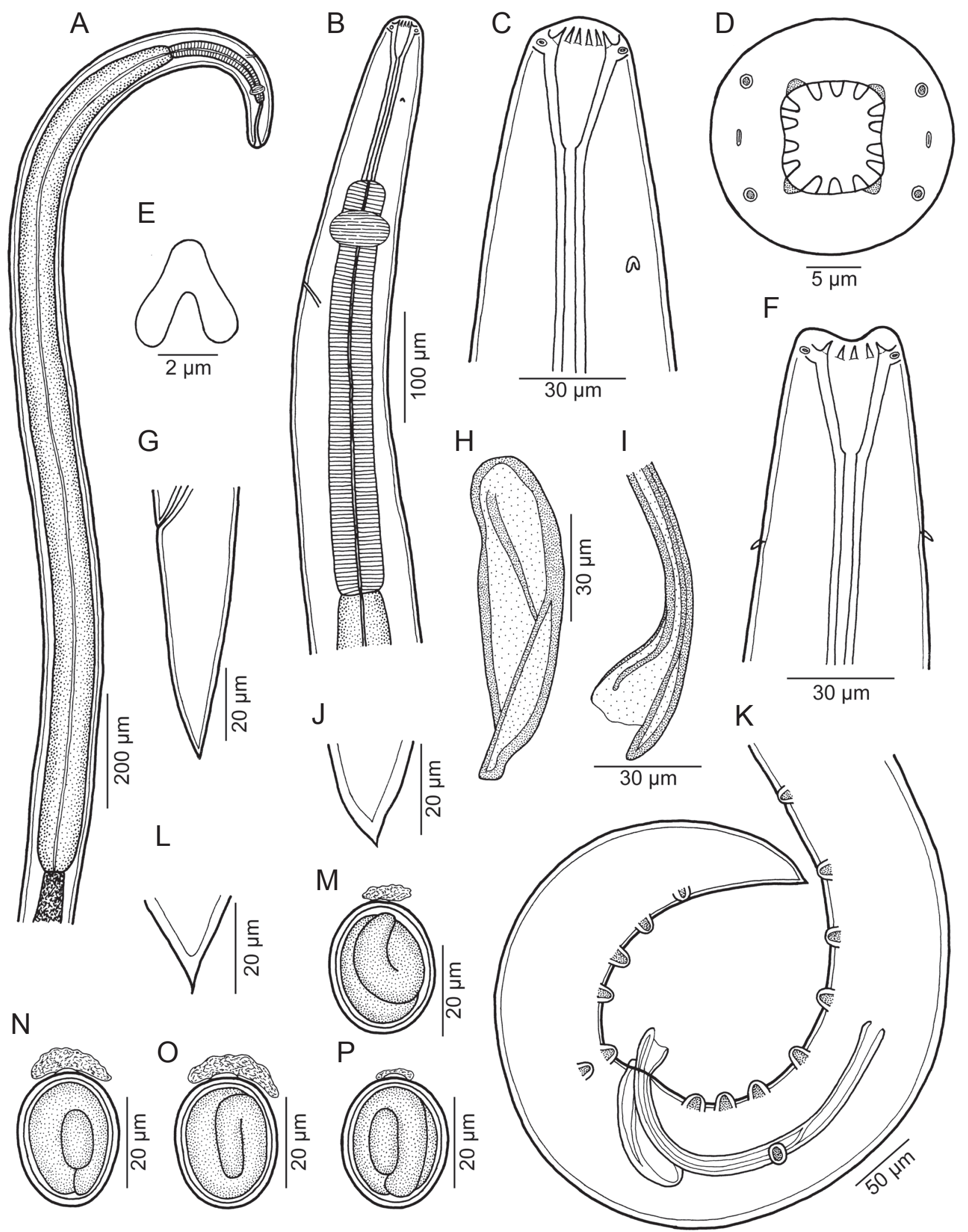

Fig. 1. Rhabdochona (Rhabdochona) centroafricana sp. n. from Barbus miolepis. A - anterior part of body of female, lateral view; B - same, higher magnification; C, D - cephalic end of female, lateral and apical views; $\mathbf{E}$ - deirid; $\mathbf{F}$ - cephalic end of female, dorsoventral view; $\mathbf{G}$ - female tail, lateral view; $\mathbf{H}$ - right spicule, lateral view; I - distal tip of left spicule, lateral view; J, L - distal tip of male and female tail, respectively; $\mathbf{K}$ - caudal end of male, lateral view; $\mathbf{M}-\mathbf{P}$ - mature eggs. 

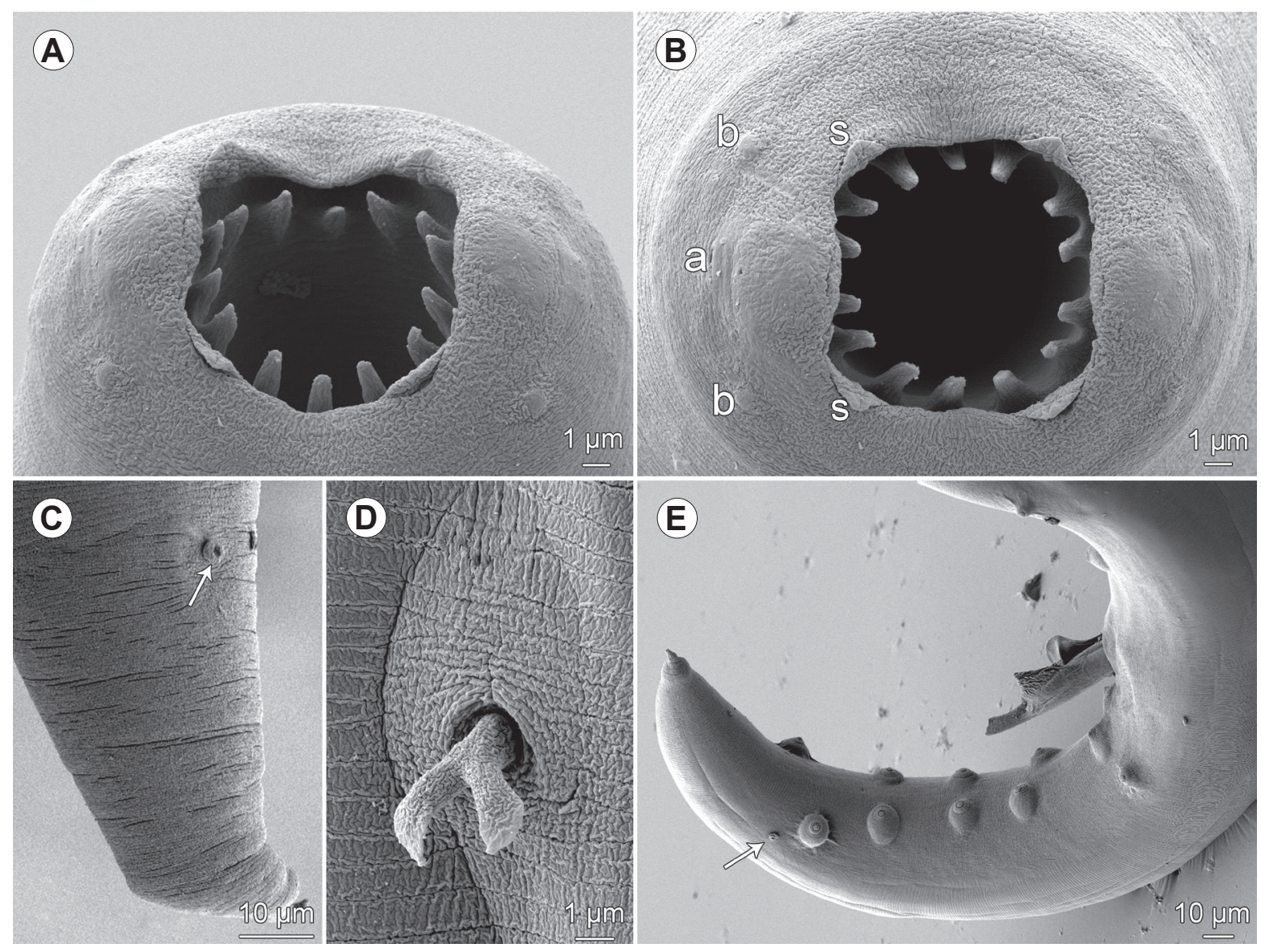

Fig. 2. Rhabdochona (Rhabdochona) centroafricana sp. n. from Barbus miolepis, scanning electron micrographs. A, B - cephalic end, subapical and apical views; C - posterior end of female tail, sublateral view (arrow indicates phasmid); $\mathbf{D}$ - deirid; $\mathbf{E}$ - tail of male, ventrolateral view (arrow indicates phasmid). Abbreviations: a - amphid; b - submedian cephalic papilla; $\mathrm{s}$ - sublabium.

pole of mature eggs of $R$. centroafricana sp. n. has been found neither in R. gendrei nor R. esseniae. Rhabdochona centroafricana is the first species of Rhabdochona exhibiting this morphological feature.

\section{Rhabdochona (Rhabdochona) marcusenii sp. n.}

Figs. 3, 4

Description: Medium-sized nematodes with finely transversely striated cuticle (Fig. 4C-E,G). Oral aperture roughly hexagonal, surrounded by 4 small triangular sublabia, 4 submedian cephalic papillae and pair of lateral amphids (Figs. 3E, 4A-C). Prostom funnel-shaped, without basal teeth (Fig. 3A-D). Prostom lined internally with longitudinal ribs forming anteriorly 14 small forwardly directed teeth ( 3 dorsal, 3 ventral and 4 lateral on either side) (Figs. 3E, 4A); exceptionally some teeth fused together or absent (Fig. 4B). Vestibule straight, relatively long (Fig. 3A-C). Deirids medium-sized, simple, situated somewhat posterior to prostom (Figs. 3B-D,F, 4C,E). Length ratio of muscular and glandular oesophagus 1 : 3.9-7.7. Posterior part of glandular oesophagus somewhat narrower than middle part. Tail of both sexes slender, conical, with rounded tip (Figs. 3G-I,L, 4F).
Male (10 specimens; measurements of holotype in parentheses): Length of body 8.09-9.82 (9.10) mm, maximum width $82-122$ (122). Length of vestibule including prostom 114-135 (126); prostom 21-24 (24) long, 15-18 (18) wide. Muscular oesophagus 222-390 (305) long, maximum width 21-24 (21); glandular oesophagus 1.48-1.75 (1.67) mm long, maximum width 33-66 (33); length ratio of both parts of oesophagus $1: 4.4-7.7$ ( $1: 5.5)$. Entire oesophagus and vestibule representing 21-25 (23)\% of body length. Nerve ring, deirids and excretory pore 162-216 (213), 45-51 (48) and 249-300 (294), respectively, from anterior extremity. Area rugosa absent.

Preanal papillae: subventral papillae occurred in following combinations: $5+5,6+6,7+7$ and $6+8$; lateral pair not observed (Fig. 3L). Postanal papillae: 6 pairs, second pair lateral, remaining pairs subventral (Figs. 3L, 4D).

Left spicule 453-486 (486) long, length of shaft 255-282 (258), representing 53-58 (53)\% of spicule length; distal tip of spicule somewhat expanded, provided with cuticular membrane (Fig. 3K). Right spicule 90-105 (93) long, with slightly outlined dorsal barb at distal end 
Moravec and Jirků: Rhabdochona spp. in Central African Republic

A
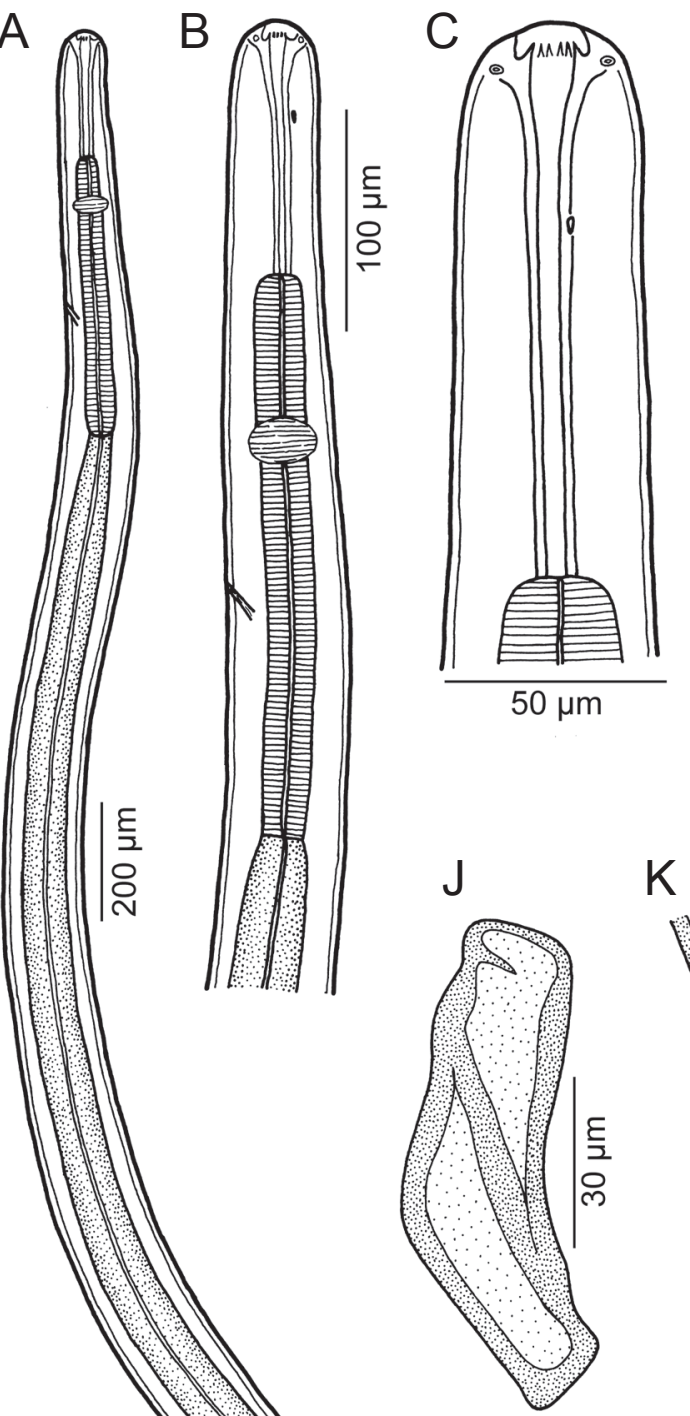

$\mathrm{D}$

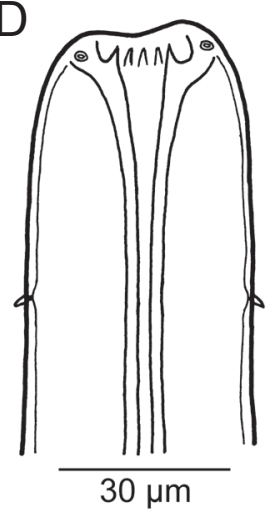

$\mathrm{E}$

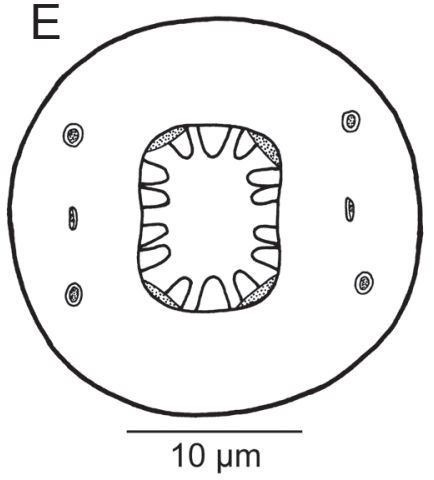

$\mathrm{H} \quad \mathrm{I}$
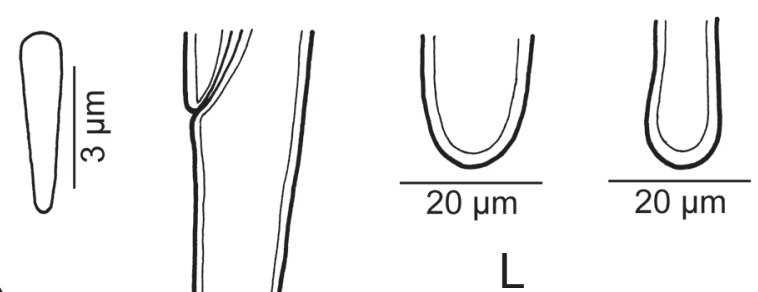

G

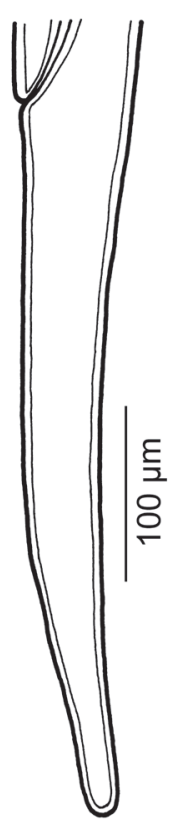

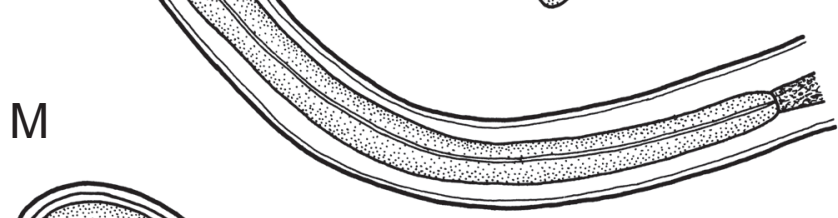

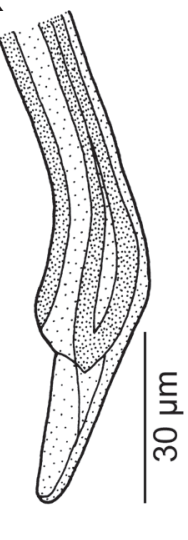

$\mathrm{M}$

$\mathrm{N}$
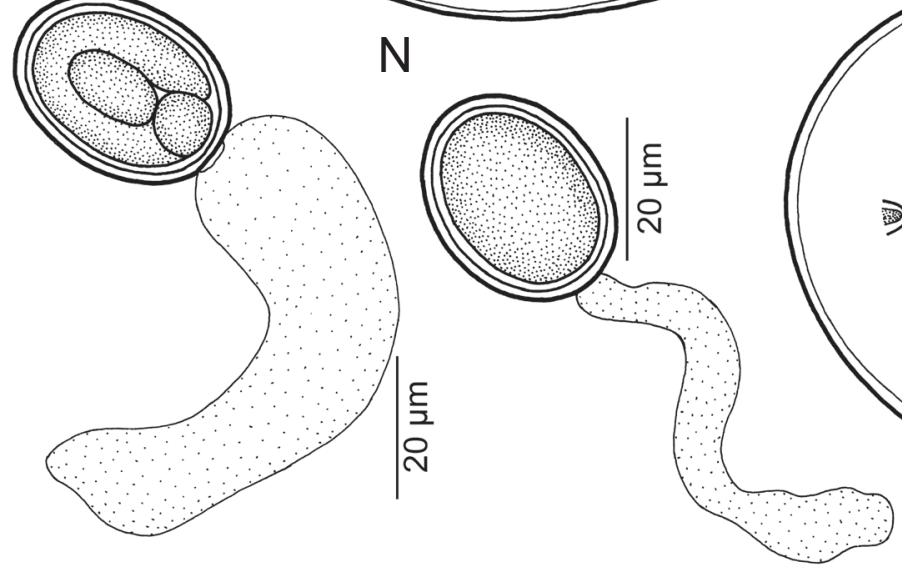

Fig. 3. Rhabdochona (Rhabdochona) marcusenii sp. n. from Marcusenius greshoffii. A - anterior part of body of male, lateral view; $\mathbf{B}$ - same, higher magnification; $\mathbf{C}-\mathbf{E}$ - cephalic end of female, lateral, dorsoventral and apical views, respectively; $\mathbf{F}$ - deirid; $\mathbf{G}$ - female tail, lateral view; $\mathbf{H}, \mathbf{I}$ - distal tip of female and male tail, respectively; $\mathbf{J}$ - right spicule, lateral view; $\mathbf{K}$ - distal tip of left spicule, lateral view; $\mathbf{L}$ - caudal end of male, lateral view; $\mathbf{M}$ - mature egg; $\mathbf{N}$ - immature egg. 

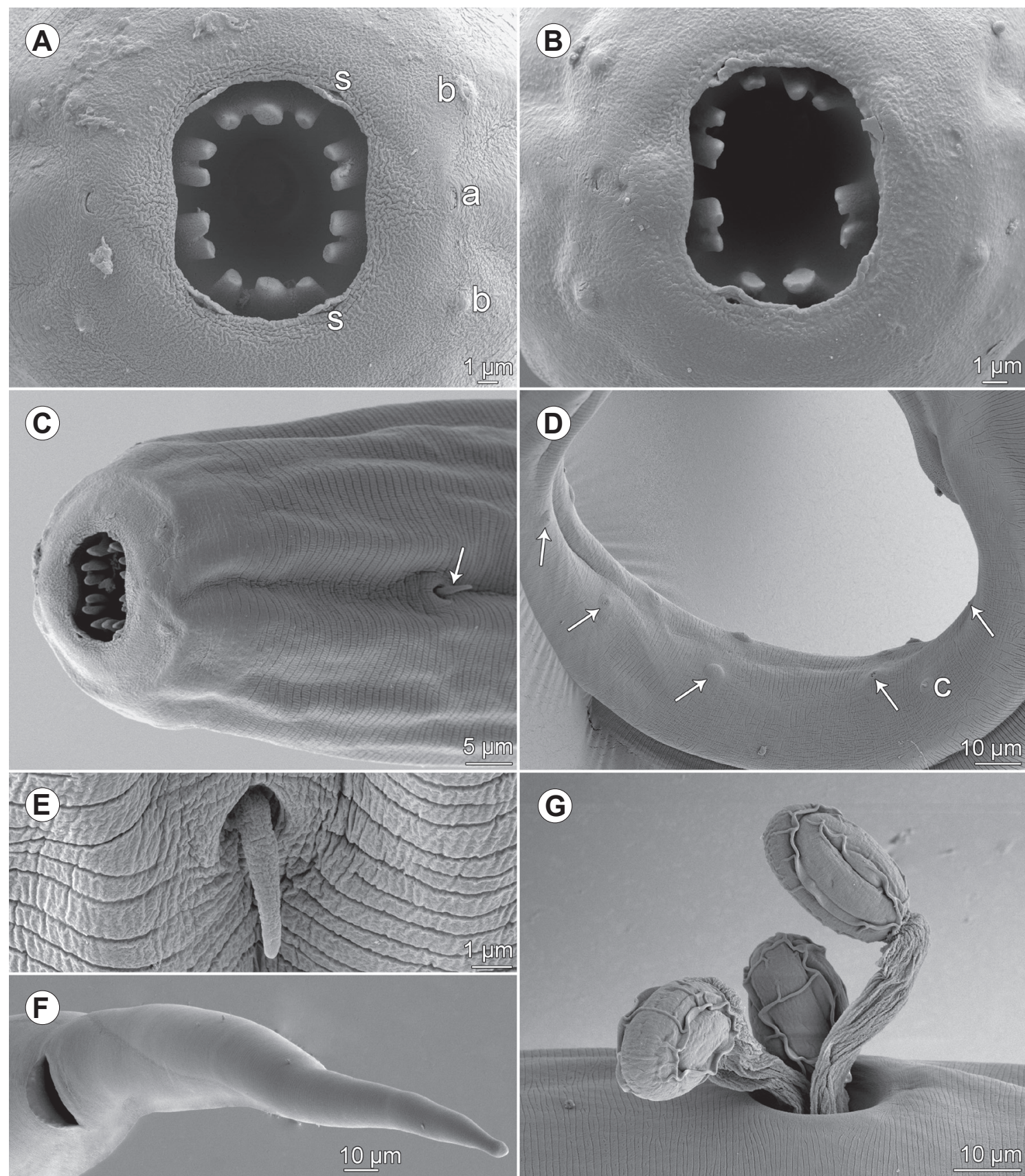

Fig. 4. Rhabdochona (Rhabdochona) marcusenii sp. n. from Marcusenius greshoffi, scanning electron micrographs. A - cephalic end, apical view; $\mathbf{B}$ - cephalic end of other specimen with atypical number of anterior teeth, apical view; $\mathbf{C}$ - anterior end, lateral view (arrow indicates deirid); D - tail of male, ventrolateral view (arrows indicate subventral postanal papillae); $\mathbf{E}$ - deirid; $\mathbf{F}$ - tail of female, ventral view; G - eggs leaving vulva, lateral view. Abbreviations: a - amphid; b - submedian cephalic papilla; c - lateral postanal papilla; s - sublabium.

(Fig. 3J). Length ratio of spicules $1: 4.82-5.23(1: 5.23)$. Tail 330-444 (417) long.

Female (5 gravid specimens; measurements of allotype in parentheses): Length of body $14.80-18.48$ (18.44) mm, maximum width 150-218 (218). Length of vestibule including prostom 111-138 (123); prostom 27-30 (30) long, 21-24 (24) wide. Muscular oesophagus 360-495 (495) long, maximum width 21-30 (27); glan- dular oesophagus 1.81-2.52 (1.95) mm long, maximum width 54-81 (75); length ratio of both parts of oesophagus $1: 3.9-5.8(1: 3.9)$. Entire oesophagus and vestibule representing $14-17(14) \%$ of body length. Nerve ring, deirids and excretory pore 210-240 (216), 51-66 (66) and 300-366 (345), respectively, from anterior extremity. Tail conical, 381-490 (449) long, with rounded tip. 
Vulva postequatorial, 8.22-10.49 (9.43) mm from anterior extremity, at $51-57$ (51)\% of body length; vulval lips not elevated. Vagina directed posteriorly from vulva. Fully developed eggs oval, smooth, thin-shelled, larvated; size $(\mathrm{n}=15) 33-36 \times 24-27(33-36 \times 24-27)$. One egg pole provided with small operculum bearing broad gelatinous filament 33-45 long and 21-24 wide; filament on immature eggs distinctly narrower and longer, 60-90 long and 9-18 wide; operculum on immature eggs indistinct (Figs. 3M,N, 4G).

Type host: Marcusenius greshoffii (Schilthuis) (Osteoglossiformes: Mormyridae), standard body length $14.5 \mathrm{~cm}$.

Site of infection: Intestine.

Type locality: Sangha River adjacent to Sangha Lodge (2 ${ }^{\circ} 59^{\prime} 7^{\prime \prime N}$; 16 16 13'58"E) (Congo River basin), DSPA, Central African Republic (collected 13 September 2012).

Prevalence and intensity of infection: 1 fish infected/2 fish examined; 16 nematodes.

Deposition of type specimens: Helminthological Collection of the Institute of Parasitology, BC AS CR (IPCAS, $\mathrm{N}$ - 1027). Symbiotype voucher not deposited, its tissue sample in pure ethanol deposited in the Department of Ichthyology, American Museum of Natural History, USA and the photograph of the type host deposited together with the type material of $R$. marcusenii.

Etymology: The specific name of this nematode relates to the genitive form of the generic name of the type host.

Remarks. In possessing 14 anterior prostomal teeth and no ornamentations at the tip of the tail, these nematodes also belong to the nominotypical subgenus Rhabdochona. The new species is the first known representative of the genus Rhabdochona characterised by the presence of a filament only on one egg pole; eggs of other species of Rhabdochona are either provided with filaments or polar caps on both poles or the eggs bear lateral swellings (floats); the surface of eggs in some species is smooth, without any polar or lateral formations (Moravec 2010).

Other important features that characterize $R$. marcusenii sp. n. and by which it differs from the majority of its congeners is, in particular, the presence of simple deirids, the prostom without basal teeth, shape of spicules, the slender, long tail with a rounded tip in both sexes and an unusually thin shell of mature eggs. Rhabdochona marcusenii is the first nominal species of the genus reported from a fish belonging to the order Osteoglossiformes. Larva of Rhabdochona sp. was recorded from Mormyrops caschive Linnaeus (Mormyridae) in the Democratic Republic of Congo (Khalil and Polling 1997).

\section{Rhabdochona (Globochona) paski Baylis, 1928}

Syns: Rhabdochona congolensis Campana-Rouget, 1961; R. aegyptiaca El-Naffar et Saoud, 1974; R. versterae Boomker et Petter, 1993

Description of male (1 specimen): Body $11.42 \mathrm{~mm}$ long, maximum width 177 . Length of vestibule includ- ing prostom 201. Prostom 42 long, 30 wide, armed with 8 anterior teeth; basal teeth present. Deirids simple, 93 from anterior extremity. Muscular oesophagus 476 long, 51 wide; glandular oesophagus $3.60 \mathrm{~mm}$ long, 123 wide; length ratio of both parts of oesophagus 1 : 7.6. Entire oesophagus and vestibule representing $34 \%$ of body length. Nerve ring and excretory pore 252 and 517 from anterior end of body. Area rugosa formed by numerous transverse bands, separated from each other by band-like fields bearing many low, longitudinal, parallel ridges. Preanal papillae: $14+15$ subventral papillae and 2 pairs of lateral papillae. Postanal papillae: 6 pairs, of which 5 pairs subventral and 1 pair lateral. Left spicule 222 long, length of shaft 75 , representing $34 \%$ of spicule length. Right spicule 90 long. Length ratio of spicules $1: 2.47$. Tail 255 long, with rounded tip.

Host: Phenacogrammus aurantiacus (Pellegrin) (Alestidae: Characiformes), standard body length $6.7 \mathrm{~cm}$.

Site of infection: Intestine.

Locality: Small forest stream near Mongambe research camp ( $2^{\circ} 55^{\prime} 4^{\prime \prime N}$; 16 23'20"E) (Congo River basin), DSPA, Central African Republic (collected 22 September 2012).

Prevalence and intensity of infection: 1 fish infected/5 fish examined; 1 nematode.

Deposition of voucher specimen: Helminthological Collection of the Institute of Parasitology, BC AS CR (IPCAS; $\mathrm{N}$ - 997). Voucher of $P$. aurantiacus is deposited, together with tissue sample in absolute alcohol, in the Department of Ichthyology, American Museum of Natural History, USA (AMNH 260346; field number CAR_T_098).

Remarks. The morphology and measurements of the only available male specimen show that it belongs to Rhabdochona $(G$.) paski Baylis, 1928 as it has been recently redescribed by Moravec et al. (2013). Although this widely distributed African species was recorded from many fish species belonging to different families and orders, most of them probably only serve as paratenic, paradefinitive or postcyclic hosts. According to Moravec et al. (2013), true definitive hosts of $R$. paski appear to be characiform species belonging to some genera of the family Alestidae (e.g. Alestes, Brycinus, Hydrocynus). The present finding of $R$. paski in $P$. aurantiacus (a new host record) supports this presumption.

\section{Rhabdochona (Globochona) tricuspidata sp. n.}

Figs. 5-7

Description: Medium-sized nematodes. Cuticle finely transversely striated, with numerous short longitudinal ridges (Fig. 6C,D,H). Body of male with narrow lateral alae (Fig. 6A), starting at about level of anterior end of glandular oesophagus and extending posteriorly some distance anterior to region of preanal papillae; lateral alae not present in females (Fig. 6C). Oral aperture hexagonal, with 4 submedian sublabia, surrounded by 4 small submedian cephalic papillae and pair of lateral amphids 


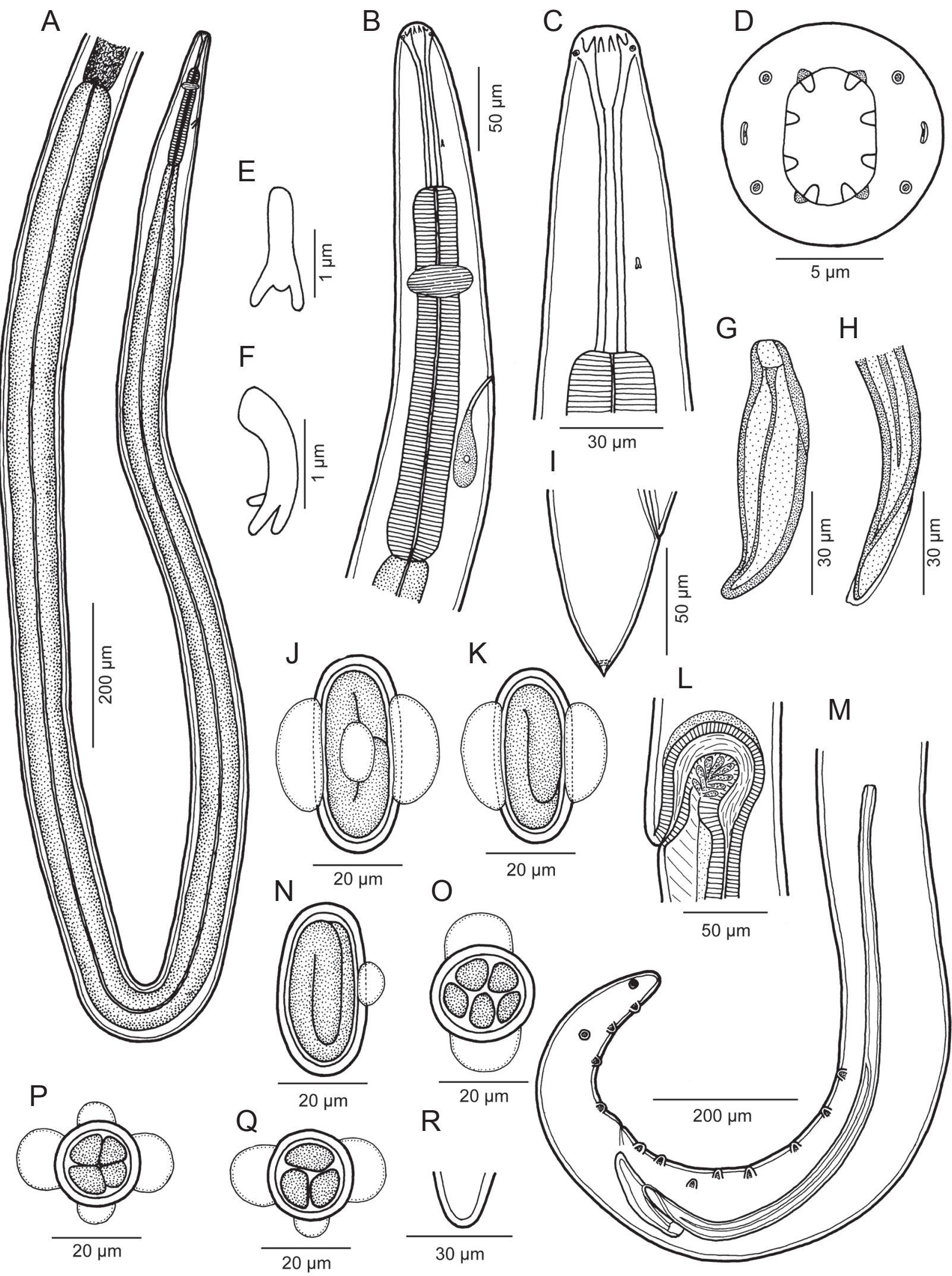

Fig. 5. Rhabdochona (Globochona) tricuspidata sp. n. from Raiamas christyi. A - anterior part of body of male, lateral view; B, $\mathbf{C}$ - anterior end of female, lateral views; $\mathbf{D}$ - cephalic end, apical view; E, F - deirid, two different views; $\mathbf{G}$ - right spicule, lateral view; $\mathbf{H}$ - distal tip of left spicule, lateral view; $\mathbf{I}$ - tail of female, lateral view; $\mathbf{J}, \mathbf{K}, \mathbf{N}$ - different eggs, lateral views; $\mathbf{L}$ - region of vulva, lateral view; $\mathbf{M}$ - posterior end of male, lateral view; $\mathbf{O}-\mathbf{Q}$ - different eggs, apical views; $\mathbf{R}$ - tail tip of male. 

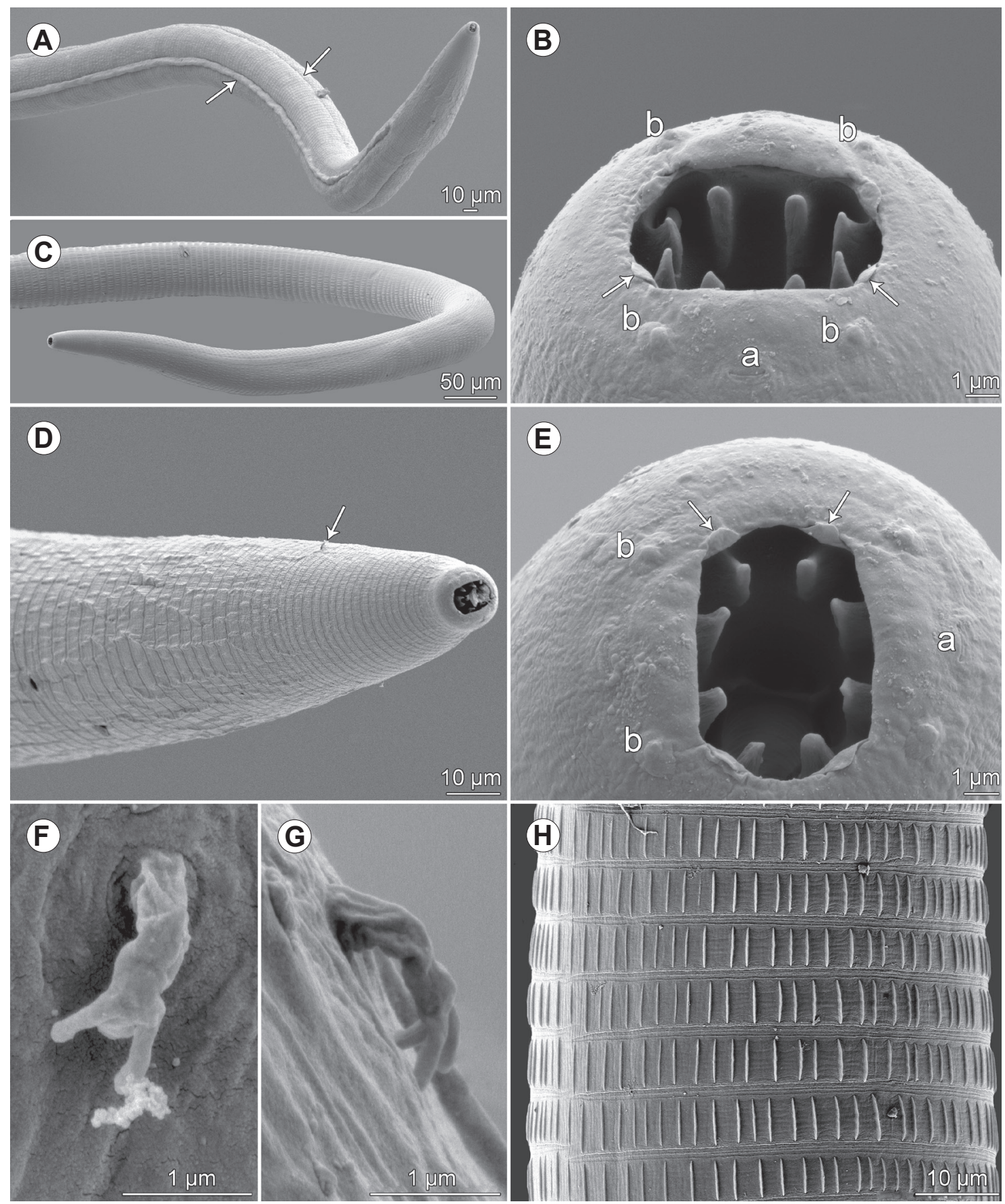

Fig. 6. Rhabdochona (Globochona) tricuspidata sp. n. from Raiamas christyi, scanning electron micrographs. A - anterior part of body of male (arrows indicate lateral alae); B - cephalic end of female, subapical view (arrows indicate sublabia); C - anterior part of body of female; $\mathbf{D}$ - anterior end of male, dorsoventral view (arrow indicates deirid); $\mathbf{E}$ - cephalic end of female, apical view (arrows indicate sublabia); F, G - deirid, different views; $\mathbf{H}$ - cuticular ornamentation on female body. Abbreviations: a - amphid; $\mathrm{b}$ - submedian cephalic papilla.

(Figs. 5D, 6B,E). Prostom funnel-shaped, with slightly outlined basal teeth (Fig. 5C). Anterior margin of prostom armed internally with 8 forwardly directed teeth (2 dorsal, 2 ventral and 2 on each side) (Figs. 5D, 6B,E). Vestibule transversely striated, long (Fig. 5B,C). Deirids very small, situated at posterior half of vestibule (Figs. 5B,C,
6D); distal end of each deirid divided into 3 short prongs of which middle one curved to body surface (Figs. 5E,F, $6 \mathrm{~F}, \mathrm{G})$. Glandular oesophagus 13-16-times longer than muscular oesophagus, occupying entire width of body (Fig. 5A). 

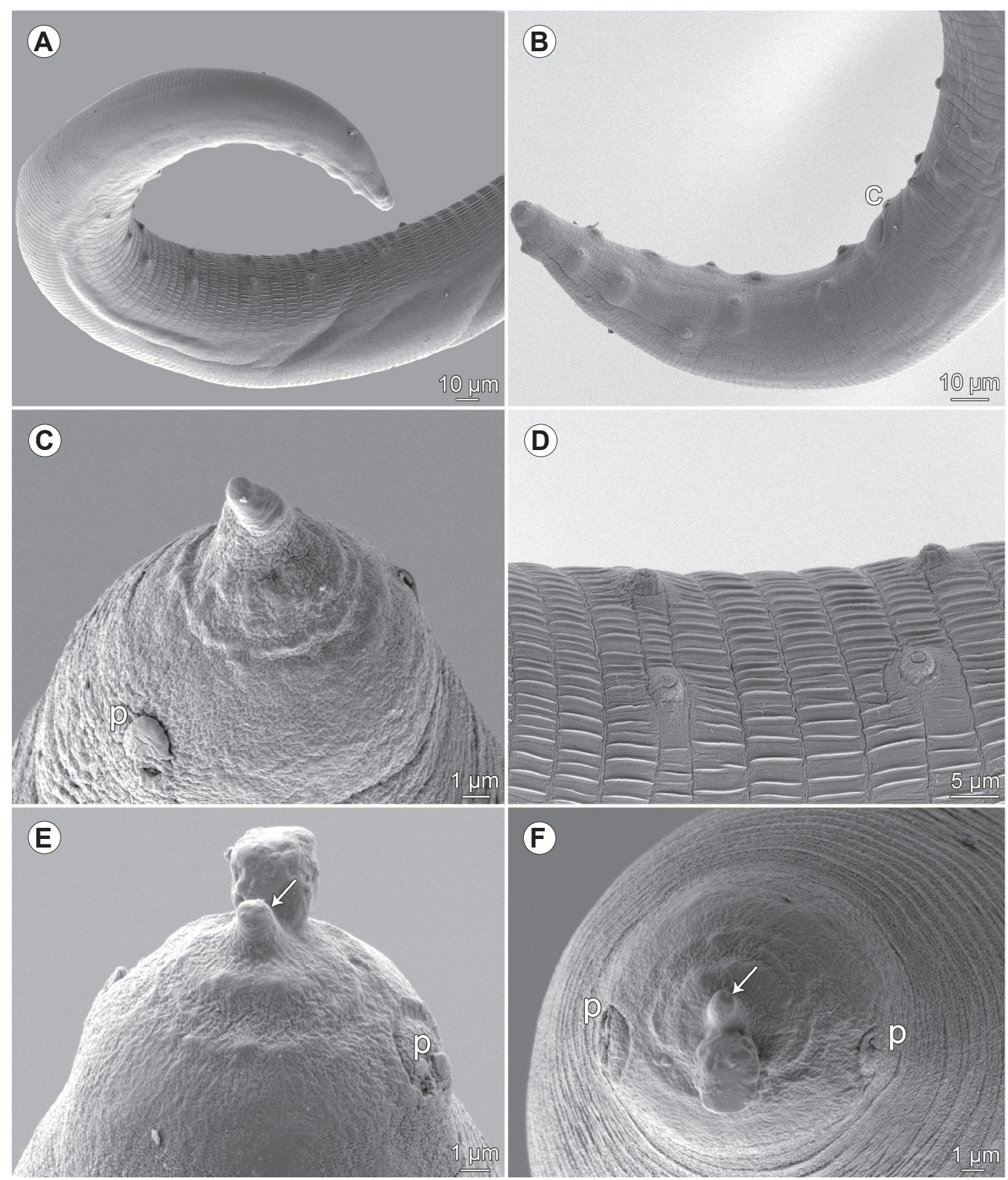

Fig. 7. Rhabdochona (Globochona) tricuspidata sp. n. from Raiamas christyi, scanning electron micrographs. A - posterior end of male, ventrolateral view; B - tail of male, sublateral view; $\mathbf{C}$ - tail tip of female, subapical view (note minute protuberances surrounding terminal spike); D - ventral precloacal cuticular ornamentations of male, ventrolateral view; $\mathbf{E}, \mathbf{F}$ - tail tip of female (other specimen), dorsoventral and apical views, big formation near terminal spike probably represents artifact (arrow indicates terminal spike). Abbreviations: c - cloacal opening; $\mathrm{p}$ - phasmid.

Male (1 specimen, holotype): Length of body $6.65 \mathrm{~mm}$, maximum width 99. Prostom 15 long and 12 wide in lateral view. Length of vestibule including prostom 93. Muscular oesophagus 180 long, maximum width 30; glandular oesophagus $2.84 \mathrm{~mm}$ long, maximum width 69 ; length ratio of both parts $1: 16$. Length of vestibule with prostom and entire oesophagus forms $47 \%$ of body length. Nerve ring encircling muscular oesophagus 135 from anterior extremity; excretory pore at 210 . Deirids not located. Preanal papillae: 8 subventral pairs of which papillae of third pair (counting from cloacal aperture) situated more laterally (Figs. 5M, 7A). Postanal papillae: 6 pairs, of which 
4 pairs subventral and 2 (third and sixth) lateral (Figs. 5M, 7B). Precloacal ventral cuticular ornamentation (area rugosa) formed by numerous transverse bands separated from each other by single transverse groove, each provided with band-like field bearing many low longitudinal, parallel ridges (Fig. 7A,D). Left spicule 501 long; its shaft 216 long, representing $43 \%$ of entire spicule length; distal tip of spicule blunt, provided with small cuticular membrane (Fig. 5H,M). Right spicule boat-shaped, 93 long, without usual dorsal barb at distal tip (Fig. 5G,M). Length ratio of spicules $1: 5.39$. Tail conical, 177 long, with rounded tip (Figs. 5M,R, 7A,B).

Female ( 3 specimens with mature eggs, measurements of allotype in parentheses; measurements of 1 juvenile specimen without eggs in square brackets): Length of body 9.91-10.27 (10.00) [6.65] mm, maximum width 123-135 (135) [87]. Prostom 24 (24) [24] long and 18 (18) [18] wide in lateral view. Length of vestibule including prostom 99-108 (99) [78]. Muscular oesophagus 213-240 (228) [186] long, maximum width 30-33 (33) [24]; glandular oesophagus 3.33-3.59 (3.59) [2.38] mm, maximum width 99-105 (99) [72]; length ratio of both parts $1: 15-16(1: 16)[1: 13]$. Anterior ovary not reaching anteriorly level of oesophagus (Fig. 5A). Length of vestibule with prostom and entire oesophagus forms 37-39 (39) [40]\% of body length. Nerve ring, excretory pore and deirids at 138-153 (138) [132], 240-243 (243) [186] and 81-99 (90) [not located], respectively, from anterior extremity.

Vulva postequatorial, 6.54-6.75 (6.54) [4.19] $\mathrm{mm}$ from anterior extremity, at 65-66 (65) [63] \% of body length. Vagina directed first anteriorly and then posteriorly from vulva (Fig. 5L). Mature eggs oval, thick-walled, larvated, usually provided with 2 large oval, almost opposite lateral swellings (Fig. 5J,K,N-Q); some eggs bearing 1 or 2 additional, smaller equatorial swellings situated between 2 large swellings (Fig. 5J,P,Q); infrequently mature eggs with only 1 swelling (Fig. 5N); swellings absent or poorly developed on immature eggs. Size of mature eggs without swellings $(n=20) 42-48 \times 21-27(42-45 \times 21)$ [-], eggwall 3 (3) thick; swellings 3-9 (6-9) high. Tail conical, short, 75-84 (84) [81] long (Fig. 5I), with small caudal spike 5-6 (6) [not measured] long and 3-4 (3) wide at tip (Figs. 5I, 7C,E,F). Tail tip surrounding caudal mucron with numerous minute cuticular elevations (Fig. 7C,E,F). Pair of marked lateral phasmids present near tail tip (Fig. 7C,E,F).

Type host: Raiamas christyi (Boulenger) (Cypriniformes: Cyprinidae), standard body length $7.5 \mathrm{~cm}$.

Site of infection: Intestine.

Type locality: Small forest stream near Mongambe research camp (2॰55'4"N; 16²3'20"E) (Congo River basin), DSPA, Central African Republic (collected 18 September 2012).

Prevalence and intensity of infection: 1 fish infected/ 3 fish examined; 7 nematodes.
Deposition of type specimens: Helminthological Collection of the Institute of Parasitology, BC AS CR (IPCAS; $\mathrm{N}$ - 1028). Symbiotype voucher of $R$. christyi is deposited, together with tissue sample in absolute alcohol, in the Department of Ichthyology, American Museum of Natural History, USA (AMNH 260336; field number CAR_T_075).

Etymology: The specific name tricuspidata is derived from the Latin adjective tricuspis (= three-spiked) and relates to the unique morphological feature of this species, i.e. the presence of deirids provided with three prongs.

Remarks. Based on the number (eight) of prostomal teeth and the presence of minute caudal projections on the tip of the female tail, nematodes of the present material can be assigned to the subgenus Globochona Moravec, 1972, as re-diagnosed by Moravec (1975). The presence of narrow lateral alae in the male also indicates affinities to the subgenus Globochonoides Moravec, 1975, but representatives of this subgenus have only six anterior prostomal teeth and both males and females possess long lateral alae (Moravec et al. 2012a).

Of the Rhabdochona (Globochona) species, only the following seven are characterised by the eggs provided with conspicuous lateral swellings (floats): $R$. (G.) bariliusi Soota et Sarkar, 1981 from Barilius bendelisis (Hamilton) in India; R. (G.) barusi Majumdar et De, 1971 from Barilius sp. in India; R. (G.) gambiana Gendre, 1922 from an unidentified fish, Barbus eutaenia Boulenger and Raiamas moorii (Boulenger) in Africa (Gambia and the Democratic Republic of Congo); R. (G.) rahimi Ghazi, Nisa et Bilqees, 2003 from Barilius pakistanicus Mirza et Sadiq in Pakistan; R. (G.) rasborae Moravec et Kamchoo, 2012 from Rasbora paviana Tirant in Thailand; R. (G.) singhi Ali, 1956 from Glossogobius giurus (Hamilton) in India; and R. (G.) wangi Moravec et Scholz, 1991 from Bagarius bagarius (Hamilton) and Zacco platypus (Temminck et Schlegel) in China (Ali 1956, Majumdar and De 1971, Moravec 1972, Soota and Dey Sarkar 1981, Wang and Guo 1983, Moravec and Scholz 1991, Ghazi et al. 2003).

However, in contrast to the above-mentioned seven species, $R$. tricuspidata sp. n. is noted for the body with marked characteristic cuticular ornamentations, deirids branching into three prongs and for the presence of lateral alae in the male only (none of these features is reported for any Rhabdochona species). Moreover, the tail tips of both sexes are simple, without any outgrowths, in $R$. bariliusi, $R$. rahimi and $R$. singhi, whereas a well-developed spinose formation at the tail tip of both the male and female is present in $R$. rasborae; a similar spinose caudal formation is present on the tail tip of female but absent in the conspecific male in $R$. barusi and $R$. wangi.

By its general morphology, the new species is similar to R. gambiana, the only known species of Rhabdochona with eggs provided with lateral swellings in Africa. Gendre (1922) inadequately described $R$. gambiana from an unidentified fish in the Gambia River, Gambia. Later 

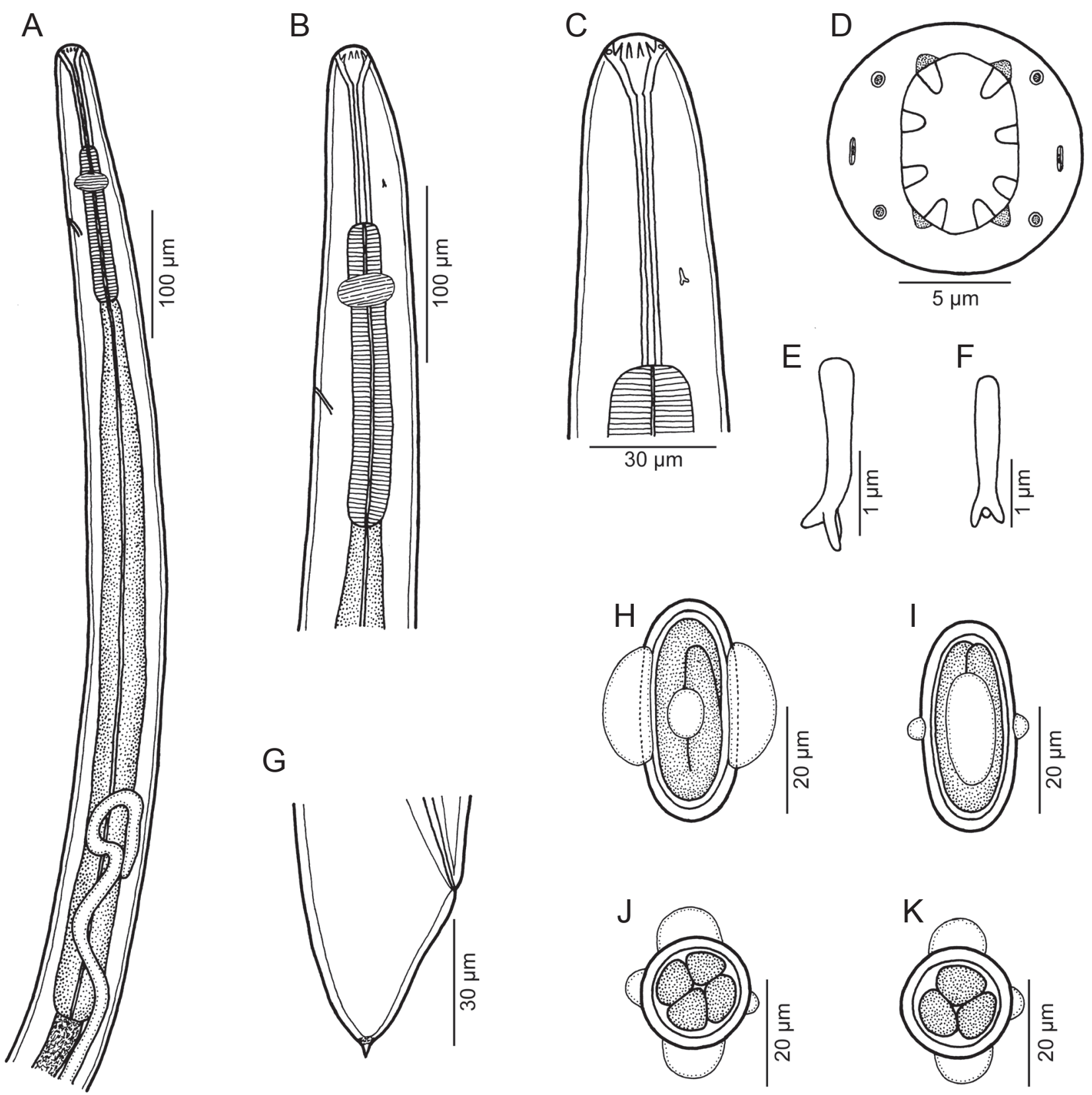

Fig. 8. Female of Rhabdochona (Globochona) sp. from Epiplatys multifasciatus. A - anterior part of body of female, lateral view; $\mathbf{B}, \mathbf{C}$ - anterior end of female, lateral views; $\mathbf{D}$ - cephalic end, apical view; $\mathbf{E}, \mathbf{F}$ - deirid, different views; $\mathbf{G}$ - tail of female, lateral view; H, I - different eggs, lateral views; J, K-different eggs, apical views.

Rodhain and Vuylsteke (1934) established Cystidicola minuta from B. eutaenia in the Kalemic River, the Democratic Republic of Congo, which was subsequently synonymised with $R$. gambiana by Campana-Rouget (1961). The latter author recorded $R$. gambiana from $R$. moorii in Lake Kivu, the Democratic Republic of Congo. Unfortunately, the type specimens of $R$. gambiana are not preserved (see Moravec 1972). Type specimens of C. minuta were re-examined by Ko and Anderson (1969), and by Moravec (1972) who was the first to observe numerous minute cuticular points at the female tail tip of this spe- cies. Rhabdochona gambiana has not been studied by SEM and it cannot be excluded that subsequent records of this parasite included in fact more than a single species.

Nevertheless, the new species differs from $R$. gambiana in the number of anterior prostomal teeth (8vs 12 - see Gendre 1922, Campana-Rouget 1961), the presence ( $v s$ absence) of lateral alae in male, the body length of gravid female (9.91-10.27 mm vs 19.15-20.47 mm - see Gendre 1922), the muscular/glandular length ratio of male oesophagus (1:16 vs $1: 10)$, a markedly shorter tail of gravid female (75-84 vs 280-290) and in the shape of 

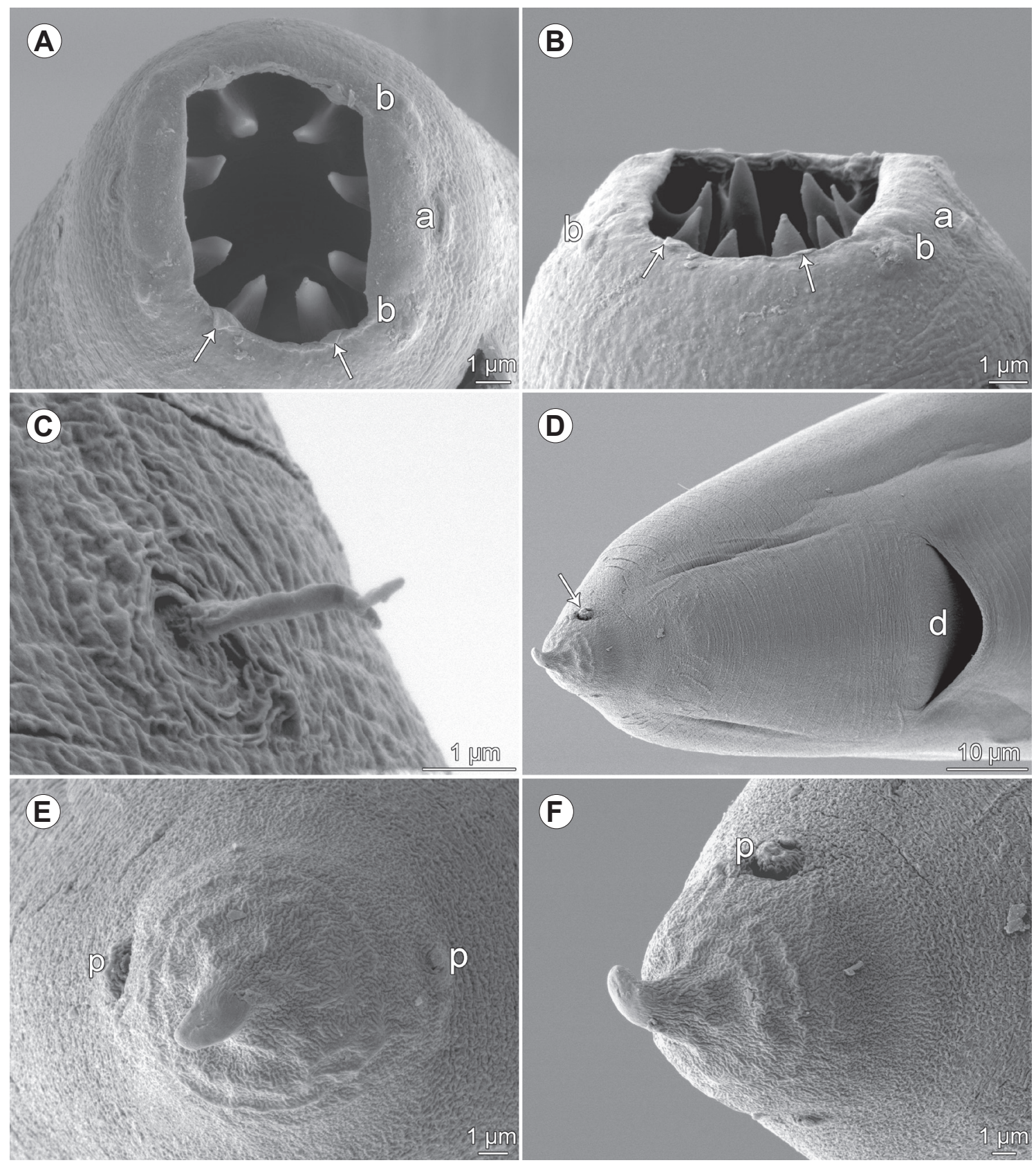

Fig. 9. Female of Rhabdochona (Globochona) sp. from Epiplatys multifasciatus, scanning electron micrographs. A, B - cephalic end, apical and subapical views (arrows indicate sublabia); C - deirid; D - tail, ventral view (arrow indicates phasmid); E, F - tip of tail, apical and dorsoventral views; note minute protuberances surrounding terminal spike. Abbreviations: $\mathrm{a}$ - amphid; $\mathrm{b}$ - submedian cephalic papilla; $\mathrm{d}$ - anus; $\mathrm{p}$ - phasmid.

deirids (branching into three prongs $v s$ allegedly simple). The latter feature is unique among all species of Rhabdochona and all representatives of the Rhabdochonidae. Within spirurine nematodes parasitising fishes, trident-like deirids were previously recorded only in Ascarophisnema tridentatum Moravec et Justine, 2010, a stomach parasite of the marine fish Gymnocranius euanus (Günther) off New Caledonia, which belongs to the related family Cystidicolidae (Moravec and Justine 2010).

\section{Rhabdochona (Globochona) sp.}

Figs. 8, 9

Description of female ( 3 specimens with mature eggs): Medium-sized nematodes. Cuticle finely transversely striated; short longitudinal ridges indistinct. Lateral alae absent. Body 4.54-5.70 mm long, maximum width 105-123. Oral aperture hexagonal, with 4 submedian sublabia, surrounded by 4 small submedian cephalic papillae and pair of lateral amphids (Figs. 8D, 9A,B). Prostom funnel-shaped, $15-18$ long and 15 wide in lateral 
view, with slightly outlined basal teeth (Fig. 8C). Anterior margin of prostom armed internally with 8 forwardly directed teeth ( 2 dorsal, 2 ventral and 2 on each side; Figs. 8D, 9A,B). Vestibule transversely striated; length of vestibule including prostom 84-90. Deirids very small, situated at posterior half of vestibule (Fig. 8B,C); distal end of each deirid divided into 3 short prongs of which middle one curved to body surface (Figs. 8E,F, 9C). Muscular oesophagus 135-177 long, maximum width 18-24; glandular oesophagus 630-990, maximum width 30-48; length ratio of both parts $1: 5-6$. Glandular oesophagus does not occupy entire width of body; anterior ovary extends anteriorly to about last third of glandular oesophagus (Fig. 8A). Length of vestibule with prostom and entire oesophagus forms $18-24 \%$ of body length. Nerve ring, excretory pore and deirids at 129-138, 183-219 and 75 , respectively, from anterior extremity.

Vulva postequatorial, $2.50-3.24 \mathrm{~mm}$ from anterior extremity, at $55-74 \%$ of body length. Vagina directed first anteriorly and then posteriorly from vulva. Mature eggs oval, thick-walled, larvated, usually provided with two large oval, almost opposite lateral swellings (floats) (Fig. 8H-K); some eggs bearing one or two additional, smaller equatorial swellings situated between two large swellings (Fig. 8H-K); swellings absent or poorly developed on immature eggs. Size of mature eggs without swellings $(\mathrm{n}=20) 42-45 \times 21-24$, egg-wall 3 thick; swellings 3-9 high. Tail conical, short, 51-57 long (Figs. 8G, 9D), with small caudal spike 4 long at tip (Figs. 8G, 9D-F). Tail tip surrounding caudal spike with numerous minute cuticular elevations (Fig. 9D-F). Pair of marked lateral phasmids present near tail tip (Fig. 9 D-F).

Host: Epiplatys multifasciatus (Boulenger) (Cyprinodontiformes: Nothobranchiidae), standard body length $2.8^{-}$ $4.3 \mathrm{~cm}$.

Site of infection: Intestine.

Locality: Small forest stream near Mongambe research camp ( $\left.2^{\circ} 55^{\prime} 4 " \mathrm{~N} ; 16^{\circ} 23^{\prime} 20^{\prime \prime} \mathrm{E}\right)$ (Congo River basin), DSPA, Central African Republic (collected 18 September 2012).

Prevalence and intensity of infection: 2 fish infected $/ 3$ fish examined; 2-4 nematodes.

Deposition of voucher specimens: Helminthological Collection of the Institute of Parasitology, BC AS CR (IPCAS; N - 1029). Vouchers of E. multifasciatus are deposited, together with tissue samples in absolute alcohol, in the Department of Ichthyology, American Museum of Natural History, USA (AMNH 260340; field numbers CAR_T_088, 089 and 091).

Remarks. These gravid female specimens with mature eggs are morphologically very similar to those of $R$. tricuspidata sp. n., but they are distinctly smaller (body length 4.76-5.70 mm vs 9.91-10.27 mm; the female of $R$. tricuspidata $6.65 \mathrm{~mm}$ long was juvenile, without eggs) and their cuticular ornamentations are indistinct. However, the main difference between these two forms is the length of the glandular oesophagus $(0.63-0.99 \mathrm{~mm}$ vs $3.33-3.59 \mathrm{~mm}$ in $R$. tricuspidata) and the muscular/ glandular length ratio in male $(1: 5-6$ vs $1: 16)$. Whereas the anterior ovary does not reach the oesophagus in $R$. tricuspidata, it extends anteriorly to about one third of the glandular oesophagus in specimens from Epiplatys. It may well be that specimens from Epiplatys represent a different species, but this can be decided only when conspecific males are available.

\section{DISCUSSION}

With respect to the recent paper of Moravec et al. (2013), the following six valid species of Rhabdochona are known to occur in fishes in Africa including Madagascar: R. esseniae Mashego, 1990; R. gambiana Gendre, 1922; R. gendrei Campana-Rouget, 1961; R. moraveci Puylaert, 1973; R. paski Baylis, 1928; and R. srivastavai Chabaud, 1970. In addition, one species, $R$. puylaerti Moravec, 1983, was described from the frog-eating snake Causus rhombeatus (Lichtenstein) (Viperidae) in Uganda, which apparently acquired this nematode secondarily while occasionally feeding on fish definitive hosts (Moravec 1983). Accordingly, the present study extends the number of known African species of Rhabdochona to ten, but as mentioned above, further investigations will probably result in describing additional new congeneric species.

Considering the subgenera of Rhabdochona proposed by Moravec (1975), although representatives of the nominotypical subgenus Rhabdochona occur in all zoogeographical regions, those of Globochona, Globochonoides and Sinonema Moravec, 1975 are distributed only in southern and southeastern parts of Asia and those of Globochona in Africa (Moravec 2010), which is also confirmed by the results of the present paper. This indicates that there exist distinct affinities of the Ethiopian and Oriental faunae of these nematodes. Moreover, in possessing narrow lateral alae in male, the species $R$. (G.) tricuspidata sp. n. shows some affinities to Globochonoides. This species is also unique within all congeners in that its body surface has conspicuous cuticular ornamentations and deirids distally branching into three prongs.

Recent SEM studies of two African species of Rhabdochona (Globochona), R. paski and R. tricuspidata (see Moravec et al. 2013 and present paper), revealed the presence of characteristic precloacal cuticular ridges (area rugosa), very different from those found in some Rhabdochona (Rhabdochona) spp. Similar precloacal ornamentations have recently been found in two Asian species of Rhabdochona (Globochona) (R. kurdistanensis and $R$. rasborae) examined by SEM (Moravec and Kamchoo 2012, Moravec et al. 2012b). Further studies may show that it is an additional morphological feature of all species of this subgenus. 
The present study also extends the knowledge of the morphological variability within Rhabdochona spp. Until now, fully developed eggs (containing larvae) of nearly all species of this genus have been found to possess lateral swellings (floats) or filaments or caps on each pole, or with lacking such lateral or polar formations (Moravec 2010). The only record of eggs with only one short filament is that of Agrawal (1965) in R. smythi Agrawal, 1965, a parasite of Mystus vittatus (Bloch) in India, but the species is inadequately described and the line drawings of eggs indicate that only immature eggs were studied in this case. Therefore, $R$. marcusenii sp. $\mathrm{n}$. is the first species of Rhabdochona in which the eggs possesing a filament on only one pole are reliably documented. Similarly, the operculum bearing a gelatinous formation was found only on one egg pole in R. centroafricana sp. n. Although onepole-filamented eggs is a unique feature not only in species of Rhabdochona but within all representatives of the Rhabdochonidae, there are several species of Ascarophis van Beneden, 1871 (parasites of marine fishes) of the related family Cystidicolidae that possess filaments on one egg pole only (Ferrer et al. 2005).

\section{Key to African species of Rhabdochona}

1 Prostom with 8 or 12 anterior teeth - subgenus Globochona ................................................................. 2

- Prostom with 14 anterior teeth - subgenus Rhabdochona

2 Mature eggs (containing larvae) with four lateral swellings (floats). Four pairs of subventral postanal papillae. Tail tip of female with numerous minute cuticular ourgrowths 3

- Mature eggs smooth, without lateral swellings. Prostom with 8 anterior teeth. Five pairs of subventral postanal papillae. Tail tip of female rounded, smooth (that of female fourth-stage larvae with several digital outgrowths). Adults in Alestidae, larvae in many other fishes; West, Central and East Africa .......... R. paski

3 Prostom with 12 anterior teeth. Male without lateral alae. Deirids simple. Type host unknown; also in Barbus eutaenia and Raiamas moorii (Cyprinidae); Gambia, Democratic Republic of Congo ...... R. gambiana

- Prostom with 8 anterior teeth. Male with narrow lateral alae. Deirids divided into three prongs. In Raiamas christyi (Cyprinidae); Central African Republic

R. tricuspidata sp. n.

4 Left spicule longer than $0.9 \mathrm{~mm}$. Deirids bifurcate. Tail tip bluntly pointed 5

- Left spicule shorter than $0.7 \mathrm{~mm}$. Deirids bifurcate or simple. Tail tip sharply pointed

5 Deirids anterior to mid-length of vestibule. Six pairs of postanal papillae. Right spicule with dorsal barb.
Glandular oesophagus of male 1.1-1.3 mm long. Parasitic in Syciopterus fasciatus (Gobiidae); Madagascar

R. srivastavai

- Deirids posterior to mid-length of vestibule. Seven pairs of postanal papillae. Dorsal barb lacking on right spicule. Glandular oesophagus of male $3.1 \mathrm{~mm}$. Definitive host unknown (reported from frog-eating snake); Uganda R. puylaerti

6 Deirids simple ...................................................... 7

- Deirids bifurcate .................................................. 8

7 Left spicule 620-680 $\mu \mathrm{m}$ long. Mature egg smooth, nonfilamented. Tail tip pointed. In Aphyosemion cameronensis (Cyprinodontidae); Cameroon ...... R. moraveci

- Left spicule 450-490 $\mu \mathrm{m}$ long. Mature egg with single broad filament on one pole. Tail tip rounded. In Marcusenius greshoffii (Mormyridae); Central African Republic ...................................... R. marcusenii sp. n.

8 Left spicule $330 \mu \mathrm{m}$ long. One pole of mature egg with small operculum bearing distinct gelatinous formation of irregular shape. In Barbus miolepis (Cyprinidae); Central African Republic

R. centroafricana sp. $\mathrm{n}$.

- Left spicule at least $480 \mu \mathrm{m}$ long. Mature egg without any polar gelatinous formations 9

9 Right spicule without dorsal barb. Left spicule 480-530 $\mu \mathrm{m}$ long. One pole of mature egg with distinct operculum. In Barbus spp. (Cyprinidae); Gambia, Democratic Republic of Congo, Cameroon ........ R. gendrei - Right spicule with dorsal barb. Left spicule 500-560 $\mu \mathrm{m}$ long. Operculum on mature egg lacking. In Barbus spp. (Cyprinidae); South Africa ............. R. esseniae

Acknowledgements. We would like to thank the government of the Central African Republic, namely the Ministre de l'Education Nationale, de l'Alphabetisation, de l'Enseignement Superieur, et de la Recherche for providing research permits to conduct our work in the Central African Republic; World Wildlife Fund and administration of Dzanga-Sangha Protected Areas for granting research approval and assistance with obtaining permits; and the Primate Habituation Programme for providing logistical support in the field. We are also greatly indebted to Rod Cassidy and his family for generous help in the field and for allowing us to work in and use facilities of the Sangha Lodge. Great thanks go to Melanie L.J. Stiassny of the Department of Ichthyology, AMNH, New York, USA and Jouke van der Zee, Royal Museum for Central Africa, Tervuren, Belgium, for identification of examined fishes. Authors' thanks are also due to the staff of the Laboratory of Electron Microscopy, Institute of Parasitology, Biology Centre of the AS CR, České Budějovice for their technical assistance, and to Blanka Škoríková of the same Institute for help with illustrations. This study was partly supported by the Czech Science Foundation (grant No. P505/12/ G112) and the Institute of Parasitology, BC AS CR (institutional support RVO: 60077344). 
Agrawal V. 1965: Some new nematode parasites from fresh water fishes of Lucknow. Ind. J. Helminthol. 17: 1-17.

Ali S.M. 1956: Studies on the nematode parasites of fishes and birds found in Hyderabad State. Ind. J. Helminthol. 8: 1-83.

Campana-Rouget Y. 1961: Nématodes de poissons. Résultats scientifiques de l'exploration hydrobiologique des lacs Kivu, Édouard et Albert (1952-1954) 3: 1-61.

Ferrer E., Aznar F.J., Balbuena J.A., Kostadinova A., Raga J.A., Moravec F. 2005: A new cystidicolid nematode from Mullus surmuletus (Perciformes: Mullidae) from the western Mediterranean. J. Parasitol. 91: 335-344.

Froese R., Pauly D. (Eds.) 2013: FishBase. World Wide Web electronic publication, www.fishbase.org, 10/2013.

GENDRE E. 1922: Notes d'helminthologie africaine (sixième note). Proc. Verb. Soc. Linn. Bordeaux 73: 148-156.

Ghazi R.R., Nisa N., Bilqees F.M. 2003: First report of the genus [sic] Rhabdochona (Globochona) rahimi sp. n. from a fresh water fish Brilius [sic] pakistanicus in Pakistan. Acta Parasitol. Turc. 27: 217-221.

Khalil L.F., Polling L. 1997: Check List of the Helminth Parasites of African Freshwater Fishes. University of the North, Pietersburg, $185 \mathrm{pp}$.

Ko R.C., Anderson R.C. 1969: A revision of the genus Cystidicola Fischer, 1798 (Nematoda: Spiruroidea) of the swim bladder of fishes. J. Fish. Res. Bd. Canada 26: 849-864.

Majumdar G., De N.C. 1971: Rhabdochona barusi sp. nov. from the fish Barilius sp. with the key to the Indian species of this genus. Folia Parasitol. 18: 381-384.

MAShego S.N. 1990: A new species of Rhabdochona Railliet, 1916 (Nematoda: Rhabdochonidae) from Barbus species in South Africa. Ann. Transvaal Mus. 35: 147-149.

Moravec F. 1972: A revision of African species of the nematode genus Rhabdochona Railliet, 1916. Acta Soc. Zool. Bohemoslov. 36: 196-208.

Moravec F. 1975: Reconstruction of the Nematode Genus Rhabdochona Railliet, 1916 with a Review of the Species Parasitic in Fishes of Europe and Asia. Studie ČSAV No. 8. Academia, Prague, 104 pp.
Moravec F. 1983: Rhabdochona puylaerti sp. n. (Nematoda: Rhabdochonidae) recorded from the African viper Causus rhombeatus (Lichtenstein). Folia Parasitol. 30: 313-317.

Moravec F. 2010: Some aspects of the taxonomy, biology, possible evolution and biogeography of nematodes of the spirurine genus Rhabdochona Railliet, 1916 (Rhabdochonidae, Thelazioidea). Acta Parasitol. 55: 144-160.

Moravec F., Bilal S.J., Abdullah S.M.A. 2012b: Two species of Rhabdochona (Nematoda: Rhabdochonidae) from the cyprinid fish Luciobarbus kersin (Heckel) in northern Iraq, including $R$. (Globochona) kurdistanensis sp. n. Folia Parasitol. 59: 139-147.

Moravec F., Charo-Karisa H., Jirkủ M. 2013: The morphology and systematics of Rhabdochona paski Baylis, 1928 (Nematoda: Rhabdochonidae), a widespread parasite of freshwater fishes in Africa. Syst. Parasitol. 85: 55-63.

Moravec F., Ermolenko A.V., Besprozvannykh V.V., Scholz T. 2012a: New data on the morphology of some Far-Eastern species of Rhabdochona (Nematoda: Rhabdochonidae), as revealed by SEM observations. Folia Parasitol. 59: 195-208.

Moravec F., Justine J.-L. 2010: Two new genera and species of cystidicolids (Nematoda, Cystidicolidae) from marine fishes off New Caledonia. Parasitol. Int. 59: 198-205.

Moravec F., Kamchoo K. 2012: Description of Rhabdochona (Globochona) rasborae sp. n. (Nematoda: Rhabdochonidae) from the freshwater cyprinid fish Rasbora paviana Tirant in southern Thailand. Folia Parasitol. 59: 209-215.

Moravec F., Scholz T. 1991: Observations on some nematodes parasitic in freshwater fishes in Laos. Folia Parasitol. 38: 163$178+$ Plts. I-VIII.

Rodhain J., Vuylsteke C. 1934: Cystidicola minuta n. sp. ver parasite de Barbus eutaenia, au Katanga. Rev. Zool. Bot. Afr. 24: 406-409.

Soota T.D., Dey Sarkar S.R. 1981: On some nematodes from Solan District, Himachal Pradesh, India. Rec. Zool. Surv. India 79: $169-177$.

WANG P., Guo Q. 1983: Studies on some species of helminths from freshwater fishes in Yunnan, China. Oceanol. Limnol. Sin. 14: 92-102. (In Chinese with English summary.)

Accepted 21 November 2013 